\title{
Histopathology of farmed freshwater fish infested with different helminthes
}

\author{
Amina El-Mansy ${ }^{1}$; Shadia Hamada ${ }^{2}$; Sameh Hasan ${ }^{2}$ and \\ Dief El-Sarnagawy ${ }^{1}$ \\ 1- National Institute of Oceanography \& Fisheries, Egypt \\ E-mail: el_mansy@hotmail.com \\ 2- Zoology Department, Faculty of Science, Mansoura University, Egypt
}

\begin{abstract}
Tn this study, histopathology of tissues of different cultured fishes (Cyprinus Icarpio, Clarias gariepinus, Oreochromis aureus, Sarotherodon galilaeus and Tilapia zillii) due to different helminthes had been investigated. Obviously, the direct effect of helminth parasites mainly depend on their attachment organs. Herein, helminthes belong to monogenean, digenean, cestode, nematode and acanthocephalan parasites, were identified as Cichlidogyrus halli typicus, Dactylogyrus afrobarbae, Orientocreadium batrachoides, Polyonchobothrium clarias, Paracamallanus cyathopharynx, Procamallanus laevichonchus and Acanthosentis tilapiae respectively. Severe damage occurred to the gill tissue due to the monogeneans opithohaptor. Limited lesions to the infected tissue of the fish host due to the nematodes were induced at the attachment site by the parasite buccal capsule. Deep penetration of intestinal tissue of the fish infested with the cestode Polyonchobothrium clarias was occurred due to the parasitic scolex. The digenean Orientocreadium batrachoides induced damage by its sucker at the attachment site to the infected epithelia of the host tissue as well. The acanthocephalan parasite Acanthosentis tilapiae caused severe rupture of the infected tissue by its proboscis hooks at the attachment site. Moreover, it may lead to complete decompose to intestinal tissue of the host. It is worthy to conclude that, in cases of the intense infestation negative impact of the parasite become more dangerous.
\end{abstract}

Keywords: Helminth parasites, histopathological lesions, cultured fishes., El-Serow Experimental Fish Farm, Egypt.

\section{INTRODUCTION}

There is an agreement, that helminth parasites are important agents among etiology of many fish diseases and may harm their hosts in different ways. These parasites may cause irritation, injury or atrophy of tissues and occlusions of alimentary canal, blood vessels or other ducts. Their presence may lead to certain changes in the activity of enzymes, vitamins or hormones of their hosts. Also, they may introduce toxic metabolic byproducts that may lead to deprive fish from normal feeding (Williams, 1967). 
Although, there are several studies particularly those related to the parasite morphology, it seems that histopathological investigations on most helminthes species that had been described are still scarce. The present monogeneans namely Cichlidogyrus halli typicus Price \& Kirk (1967) Paperna, 1979 and Dactylogyrus afrobarbae Paperna, 1968 from gills of tilapian fishes and Bagrus bayad were reported by Khidr (1986), El-Naggar et al. (1991), El-Mansy (1992), El-Naggar \& Khidr (1998), El-Naggar (2003) and Matter (2005). The digenean Orientocreadium batrachoides Tubangui, 1931 was isolated from the intestine of the catfish Clarias gariepinus by Ibrahim et al. (1988), Nassef (1988), ElMansy (1992), El-Naggar et al. (1993), El-Ganiny (1995) and Arafa \& Reda (2002). The cestode namely Polyonchobothrium clarias (Woodland, 1925) Meggitt, 1930 was isolated by El-Mansy (1992), El-Ganiny (1995), El-Naggar (2003), Matter (2005) and Ibrahim et al. (2008). As well as, the two nematodes namely Paracamallanus cyathopharynx Baylis, 1923 and Procamallanus laeviconchus Wedi, 1862 were also isolated from Clarias gariepinus by Nassef (1988), El-Mansy (1992), El-Naggar (2005), and Matter (2005). The acanthocephalan Acanthosentis tilapiae Baylis, 1948 was isolated from some tilapias by El-Mansy (1992) and from the intestine of Anguilla vulgaris by Nassef (1988).

Although there are some studies such as that was reported by Dezfuli et al. (1997), it seems that, the detailed study of host-parasite relationship has not been investigated yet particularly for most helminth species. This somewhat may be coincided with those reported by the latter authors that the pathogenic digeneans has not been investigated in great detail in fish. Therefore, this study tries to introduce a new vision to evaluate histological lesions induced by monogeneans digenean cestode nematode and acanthocephalan parasites in different tissues of some of economic fishes.

\section{MATERIALS AND METHODS}

Freshwater fishes belonging to families Cyprinidae, Clariidae and Cichlidae including five genera and six species of the common carp Cyprinus carpio L., karmote Clarias gariepinus Cuvier \& Valenciennes, 1840, Oreochromis aureus Steindachner, 1864, O. niloticus Linnaeus, 1757 and tilapias such as Tilapia zillii Geravais, and 1848. These fishes were caught from El-Serow experimental fish farm North-East Cairo and brought to the laboratory for parasitological examination. After dissection of the fish, different organs were removed to search for helminthes. Some infected specimens were processed for histopathological investigations. Pieces of infected fish tissue were fixed in Bouin fluid. After series of known steps the tissue was embedded in wax. Thereafter, serial sectioning of the template that contained the previously processed tissue had been done at about 4-6 $\mu \mathrm{m}$. By Heidenhain’s "Azan” modification these sections had been stained. Finally, through the microscopic examination, photographs had been picked from infested tissues with different 
helminthes. On the other hand, Azan was quoted from Lillie (1954) original from Heidenhain's (1915), also see Conn et al. (1962). The present study is quoted from a post-master's thesis, which was cleared by El-Mansy A. in 1992.

\section{RESULTS}

The different helminthes that caused histopathological lesions to tissue of the infested fish were designed as follows:

I. The monogeneans Cichlidogyrus halli typicus and Dactylogyrus afrobarbae

Cichlidogyrus halli typicus infested gills of tilapias such as Oreochromis aureus and Sarotherodon galilaeus. The parasite is firmly attached to tissue of secondary gill lamellae by its opisthohaptor particularly dorsal, ventral bars and marginal hooklets inducing degeneration of the epithelia at the attachment site (Figs. 1-3).

Dactylogyrus afrobarbae infested gill lamellae of Cyprinus carpio (Figs. 46). Necrotic changes in lamellar tissue comparable with uninfected tissue (Fig. 5), degeneration and proliferation of lamellar tissue with cellular infiltration at and around the attachment site due the parasite were induced (Fig. 6).

\section{The digenean Orientocreadium batrachoides}

Orientocreadium batrachoides infested intestine of Clarias gariepinus (Figs. 7-9). Obviously, the parasite sucker caused limited damage of mucosal epithelia as a result of detachment to intestinal villi (Figs. $8 \& 9$ ).

\section{The cestode Polyonchobothrium clarias}

Polyonchobothrium clarias infested pyloric portion of stomach of Clarias gariepinus (Figs. 10-12). This parasite deeply embedded by its scolex into the infected tissue which induced deep cavity-like depression inside mucosal tissue. Also it causes destruction of mucosal epithelia around the site of infection comparable with uninfected tissue (Fig. 11) leading to dilation of blood capillary of the infected tissue (Fig. 12).

IV- The nematodes Paracamallanus cyathopharynx and Procamallanus laeviconchus

Paracamallanus cyathopharynx infested posterior portion of intestine of Clarias gariepinus (Fig. 13). This parasite caused limited damage by its buccal capsule through the detachment of epithelial tissue between its ribs (Figs. 14\& 15).

Procamallanus laeviconchus embedded its buccal capsule in cardiac portion of stomach of Clarias gariepinus (Fig. 16) caused damage and rupture of mucosal tissue around the parasite buccal capsule (Fig. 17). Also hemorrhage at the attachment site probably resulted (Fig. 18).

\section{V- The acanthocephalan Acanthosentis tilapiae}

Acanthosentis tilapiae (Fig. 19) infested intestine of tilapias such as Sarotherodon galilaeus and Tilapia zillii. The parasite proboscis was deeply embedded with its hooks in epithelia and causes severe rupture of tissue at the attachment site (Fig. 20). This parasite seems to occupy wide area of intestinal 
lumen (Fig. 21) and may lead to decompose the whole intestinal tissue of the infested fish (Fig. 22).

\section{DISCUSSION}

Obviously, severity of lesions that induced by the helminth in the host tissue depends mainly on the parasite morphology, particularly its composition and size of the attachment organ. Infestation of the fish with monogeneans Cichlidogyrus halli typicus and Dactylogyrus afrobarbae resulted severe damage to gill lamellae may be similar to lesions that were reported by AbdelMeguid (1988). Severe alterations of gills might be negatively affected on the respiratory process of the fish. Also, Thurston (1965) discussed that, monogenean gill parasites are pathogenic in massive infestations because they damage the epithelia and cause secretion excessive amount of mucus which affects respiration. Moreover, Molnár (1971) confirmed a lethal effect of Dactylogyrus lamellatus infested grass carp fry.

In this study, limited damage of mucosal epithelia lining the intestinal villi at the attachment site was induced by ventral and oral suckers of digeneans where they may be able to fix and obtain their food. Hoffman (1975) as reported by Dezfuli et al. (1997) stated that except for Sanguinicola spp. and Crepidostomum farionis no one has reported any lesions due to adult trematodes in freshwater fishes. The latter authors also reported lesions in the alimentary canal of Anguilla anguilla associated with digeneans named Helicometra fuciata and Deropritis infiata. Amlacher (1996) as reported by Adeyemo \& Agbede (2008) reported that adult trematode may not invade organs by embedding in the tissues but only attaches to convenient site where they may be able to obtain all its nutrient requirements. In coordination with Imam (1971), Tadros et al. (1979) and Nassef (1988) reported that intestinal helminthes of freshwater fishes induced many histopathological alterations in the wall of intestinal tract.

The present cestode Polyonchobothrium clarias was deeply penetrated the pyloric portion of stomach of Clarias gariepinus by its scolex caused destruction and defection of the infected tissue, similar damage was occurred due to the infestation of intestinal mucosa of Anguilla vulgaris with Bothriocephalus barbus (Nassef, 1988). Ibrahim et al. (2008) also reported that, there were significant differences between normal fish Clarias gariepinus and infected ones with the cestode Polyonchobothrium clarias.

The infected tissue of Clarias gariepinus with the nematodes Paracamallanus cyathopharynx and Procamallanus laevichonchus showed limited detachment and degeneration. The second parasite might lead to hemorrhage at attachment site. The infestation which was clearly associated with mucoid secretion was also observed by Deardorff \& Overstreet (1980) and Matter (2005).

Acanthosentis tilapiae induced severe lesions particularly rupture the infected tissue. In addition, this acanthocephalan may cause decomposition of 
most intestinal layers; also, Nassef (1988) showed complete destruction of the intestinal villi with leukocyte infiltration due to Paragorgorhynchus albertianum infested the gastrointestinal tract of Lates niloticus. It is worthy to mention that this parasite with its big size may be led to narrowing the intestinal lumen. In addition, these lesions may indirectly accompany secondary infections, particularly of bacterial ones; this was also suggested by Tadros et al. (1979). Thereafter, quality of adequate food and then growth fish rate might be reduced due to such negative impacts.

It is obvious that the dangerous helminthes may be arranged respectively as: Acanthocephala then to be followed by Monogenea, Cestoda, Nematoda, and Digenea. Moreover it seems that Acanthosentis tilapiae, Dactylogyrus afrobarbae, Polyonchobothrium clarias and Procamallanus laeviconchus might be considered as more negative on fish health. Finally of wise particularly in the intense cases of infestation with parasites, it may be important to use a registered efficient safe medicament.

\section{ACKNOWLEDGEMENT}

First of all Praise be to ALLAH. Thanks to anyone who had provided any help. Tribute to the Spirit of Dr. Sameh Hafez Hasan, the Former Professor of Parasitology, Zoology Department, Faculty of Science-Mansoura University.

\section{REFERENCES}

Abdel-Meguid, M. (1989). Parasitological and histopathological studies on the grass carp (Ctenopharyngodon) prised in the Delta breading station in Egypt. M. Sc. Thesis in Zoology. Faculty of Science, Ain Shams Univ., Egypt.

Adeyemo A. O. and Agbede S. A. (2008). Histopathology of Tilapia tissues harboring Clinostomum tilapiae parasites. Afr. J. Biomedical Research 11: 115-118.

Arafa, S. Z. and Reda, E. S. (2002). Cholinergic components of the nervous system of the digenean parasites, Orientocreadium batrachoides, Astiotrema reniferum and Eumasenia aegyptiacus from the catfish Clarias gariepinus in Egypt. J. Egypt. Ger. Soc. Zool. 38: 75-91.

Baylis, H. A. (1923). Notes on Procamallanus spiralis (Baylis, 1923) (Nematoda). J. Parasitol. 15 (12): 137-138.

Baylis, H. A. (1948). A new acanthocephalan from an East African freshwater fish: Ann. Mag. Nat. Hist. 11 (120) 14:461-468. 
Conn, H. J.; Darrow M. A. and Emmel V. A. (1962). Staining procedures. University of Rochester, Medical center Rochester, N. Y. Second edition.

Deardorff, L. T. and Overstreet M. R. (1980). Taxonomy and Biology of North American species of Goezia (Nematoda: Anisakidae) from fishes including three new species. Gulf coast Research Laboratory, Ocean springs, Missippi 39564. Proceedings of the helminthological society of Washington, 47(2): 192-217.

Dezfuli, B. S.; Manera M.; Onestini S. and Rossi R. (1997). Histopathology of the alimentary canal of Anguilla anguilla L. associated with digenetic trematodes: a light and electron microscopic study. J. of Fish Diseases, 20: 317-322.

El-Ganiny, S. S. E. (1995). Studies on the parasites of the Nile fishes at ElMenia Governorate. Ph. D. Thesis, Faculty of Science, El-Menia Univ., Egypt.

El-Mansy, A. (1992). Histopathological studies on some parasitic infestations in freshwater fish farms in Egypt. M. Sc. Thesis Faculty of Science, Mansoura Univ., Egypt.

El-Naggar, A. M. O. (2003). Studies on helminthiasis and associated parasites in Nile fishes in Egypt. Ph. D. Thesis. Ain Shams Univ. Faculty of Science, Egypt.

El-Naggar, M. M. and Khidr, A. A. (1998). Ultrastructural observations on the anterior adhesive apparatus of the monogenean gill parasite Cichlidogyrus halli typicus. J. Egypt. Ger. Soc. Zool., 26:309-324.

El-Naggar, M. M.; Khidr, A. A. and Kearn, G. C. (1991). Ultrastructural observations on the tegument and associated structures of the monogrnean Cichlidogyrus halli typicus (Price \& Kirk, 1967) Paperna, 1979. Intern. J. Parasitol., 21: 707-713.

El-Naggar, M. M.; Ibrahim, H. A. and Hamada S. F. (1993).: Re-description of Orientocreadium batrachoides Tubangui, 1931, a digenean intestinal parasite of Clarias gariepinus in Egypt. J. Egypt. Ger. Soc. Zool., 10: 157-170.

Heidenhain, M. (1915). Über die Mallorysche Bindegwebs Farbung mit karmin und Azokarmin als Vorfarben. Ztschr. F. Wissensch. Mikr. 32: 361-72. 
Ibrahim, M. M.; Shalaby, S. I. and Mahmoud, N. A. (1988). Studies of the enteric nodular lesions in Clarias gariepinus fish induced by Orientocreadium batrachoides (Trematoda). J. Egypt. Vet. Med. Assoc.

Ibrahim, A. A.; Taha, H. A. and El-Naggar, M. M. (2008). Host-Parasite relationship between Polyonchobothrium clarias and Clarias gariepinus. The $12^{\text {th }}$ Scientific Conference of the Egyptian Society for the Development of Fisheries Resources and Human Health, Abst., Ain Shams University.

Imam, E. A. E. (1971). Morphological and Biological studies of the enteric helminthes infesting some of the Egyptian Nile fishes particularly Polyonchobothrium clarias of the karmotes Clarias gariepinus and Clarias anguillaris. Vet. Thesis, Cairo Univ., Egypt.

Khidr, A. A. (1986). Biological studies on monogenean parasites of some bony fishes inhabiting Nile Delta waters. Ph. D. Thesis Faculty of Science, Mansoura Univ., Egypt.

Lillie, R. D. (1954). Histopathologic technique and practical histochemistry. The Blakiston company, New York.

Matter, S. A. I. (2005). Effect of the parasitic infestation on the reproductive process of the River Nile fishes in Egypt. M. Sc. Faculty of Science (Girls), Al-Azhar University.

Meggitt, F. J. (1930). Report on a collection of cestodes mainly from Egypt. 4conlusion. Parasitol., 22: 338.

Molnár, K. (1971). Studies on gill parasitosis of the grass carp (Ctenopharyngodon idella) caused by Dactylogyrus lamellatus Achmerov, 1952. III-Therapy and control. Acta. Vet. Aca. Scientiarum Hungaricae, Thomus. 4(21): 337-382.

Nassef, T. M. N. (1988). Morphological studies on some gastrointestinal parasites of freshwater fishes. Vet. Thesis, Cairo Univ., Egypt.

Papernam I. (1979). Monogenea of inland water fish in Africa. Mus. Re. Afr. Cent. (Tervuren Belgique) Doc. Zool. 131p.

Paperna, I. (1968). Monogenic trematodes collected from freshwater fish in Ghana. Bamidgeh. 2 (20): 88-99. 
Price, C. E. and Kirk, R. (1967). First description of monogenetic trematodes from Malawi. Rev. Zool. Bot. Afr. 76: 137-144.

Tadros, G.; Iskandar, A. R. and Wassef, N. A. (1979). On an intestinal cestode and acanthocephalan from the Nile and Red Sea fishes with histopathological study of their habitat. J. of Egypt. Parasitol., 1(9):143-157.

Thurston, P. J. (1965). The pathogenicity of fish parasites in Uganda. Makerere Univ. College. Kampala. Proceedings of the east African Academy. III: 45-51.

Tubangui, M. A. (1931). Worm parasites of the brown rat (Mus norveqieus) in the Philippine Islands, with special reference to those forms that may be transmitted to human beings. Philippine J. Sc. 46: 531-591.

Wedi, K. (1862). Zurhelminthen fauna Ägyptein. Sitzungsber Math. Natur. W. K. Akad. Wiss., Wien, XLIV. L. 44: 463-482.

Williams, H. H. (1967). Helminth diseases of fish. Helminthol. Abst. 36: 261-295.

Woodland, W. N. F. (1925). On some remarkable Monticellia like and other cestodes from Sudanese Siluroides. Quart, J. Mic. Sc. 69:703-729.

\section{EXPLANATION OF FIGURES}

Fig. 1: A specimen of the monogenean Cichlidogyrus halli typicus (arrow) infesting gill of Oreochromis aureus, fixed in Bouin x100.

Fig. 2: Longitudinal section of gill filaments of $O$. aureus shows section of Cichlidogyrus halli typicus (black arrow). Note the difference between the tissue at the site of the attachment and uninfected lamellae (white arrow), stained with Azan, x125.

Fig. 3: High magnification of gill filament of Sarotherodon galilaeus infested with $C$. halli typicus. Note firmly attachment of the parasite in tissue of secondary gill lamellae (black arrow) by its opisthohaptor particularly dorsal, ventral bars and marginal hooklets (white arrow) inducing degeneration of the infected tissue, stained with Azan, x500.

Fig. 4: A specimen of the monogenean Dactylogyrus afrobarbae (arrow) infesting gill of Cyprinus carpio, fixed in Bouin x100.

Fig. 5: Longitudinal section of gill filaments of Cyprinus carpio shows section of $D$. afrobarbae between gill filaments (thick arrowhead). Note necrotic changes in lamellar tissue (white thick arrowhead) compared with uninfected tissue (black arrow), stained with Azan, x125. 
Fig. 6: Section of gill lamellae of $C$. carpio infested with the parasite $D$. afrobarbae (white arrow) that captured gill tissue by its opisthohaptor (arrowhead). Note degeneration and proliferation of lamellar tissue with cellular infiltration at and around the attachment site (black arrows) compared with uninfected tissue, stained with Azan, x312.5.

Fig. 7: A specimen of the digenean Orientocreadium batrachoides (arrow) isolated from intestine of Clarias gariepinus. Note also the discernible oral and ventral suckers of the parasite, fixed in Bouin $\mathrm{x} 40$.

Fig. 8: Transverse section of intestinal mucosa of $C$. gariepinus infested with $O$. batrachoides shows portion of the worm sucker (long arrow) near to the mucosal epithelia (short arrow) of the host, stained with Azan, x62.5.

Fig. 9: High magnification of intestinal mucosa of $C$. gariepinus infested with $O$. batrachoides shows limited damage of the infected tissue as a result of detachment of intestinal villi (short arrow) by the parasite sucker (long arrow), stained with Azan, x200.

Fig. 10: A specimen of the cestode Polyonchobothrium clarias (arrow) embedded by its scolex into pyloric portion of stomach of Clarias gariepinus, fixed in Bouin $\mathrm{x} 40$.

Fig. 11: Transverse section of pyloric portion of stomach of $C$. gariepinus infested with the cestode Polyonchobothrium clarias (long black arrow) that induced deep cavity-like shape inside mucosal tissue and also destruction of mucosal epithelia (white arrow) around the infection site comparable with uninfected tissue which is well noticeable (short arrow), stained with Azan, x40.

Fig. 12: High magnification of pyloric portion of stomach of C. gariepinus infested with $P$. clarias (short arrow) shows dilation of blood capillary (long arrow) near to the attachment site, stained with Azan, x3125.

Fig. 13: Specimens of the nematode Paracamallanus cyathopharynx (arrow) infested hind gut of Clarias gariepinus, fixed in Bouin x40.

Fig. 14: Transverse section of posterior portion of intestine of C. gariepinus infested with $P$. cyathopharynx. Note the parasite buccal capsule (short arrow) attached to mucosal epithelia and damage of epithelia (long arrow) at the attachment site is also well discernible, stained with Azan, $\mathrm{x} 500$.

Fig. 15: High magnification of intestinal mucosa of C. gariepinus infested with P. cyathopharynx shows detachment portion of epithelial tissue (white arrow) by the parasite ribs (black arrow). Tissue rupture could be seen at the infection site as well, stained with Azan, x500.

Fig. 16: Specimens of the nematode Procamallanus laeviconchus (arrow) embedded its buccal capsule in cardiac portion of stomach of the host Clarias gariepinus, fixed in Bouin x40.

Fig. 17: Transverse section of mucosa lining cardiac portion of stomach of $C$. gariepinus infested with $P$. laeviconchus indicates rupture of mucosal 
tissue (long arrow) around the parasite buccal capsule (short arrow), stained with Azan, x500.

Fig. 18: Transverse section of mucosa lining cardiac portion of stomach of $C$. gariepinus infested with $P$. laeviconchus shows firmly attached parasite buccal capsule (black arrowhead) to the infected portion of the tissue. Also notice damage and probably hemorrhage (white arrow) of epithelia at the attachment site comparable with uninfected tissue (white arrowhead), stained with Azan, x500.

Fig. 19: A specimen of the acanthocephalan Acanthosentis tilapiae (arrow) isolated from intestine of Sarotherodon galilaeus. Notice contraction of the parasite proboscis, fixed in Bouin, $\mathrm{x} 40$.

Fig. 20: A magnified section of intestinal mucosa of $S$. galilaeus infested with $A$. tilapiae. Notice protrusion of the parasite proboscis (white arrowhead) which deeply embedded with its hooks (black arrowhead) in epithelia and caused severe rupture (white arrow) of tissue at the attachment site, stained with Azan, x500.

Fig. 21: Transverse section of gut (white arrow) of Tilapia zillii infested with A. tilapiae (black arrow). Notice occupation wide area of intestinal lumen because of this parasite which seems somewhat of large size, stained with Azan, $x 40$.

Fig. 22: High magnification of section of gut of $T$. zillii infested with a female $A$. tilapiae (black arrow) shows absence of normal composition of intestinal tissue but seems such as decomposed remnants of fibrous tissue (white arrow), stained with Azan, x125. 

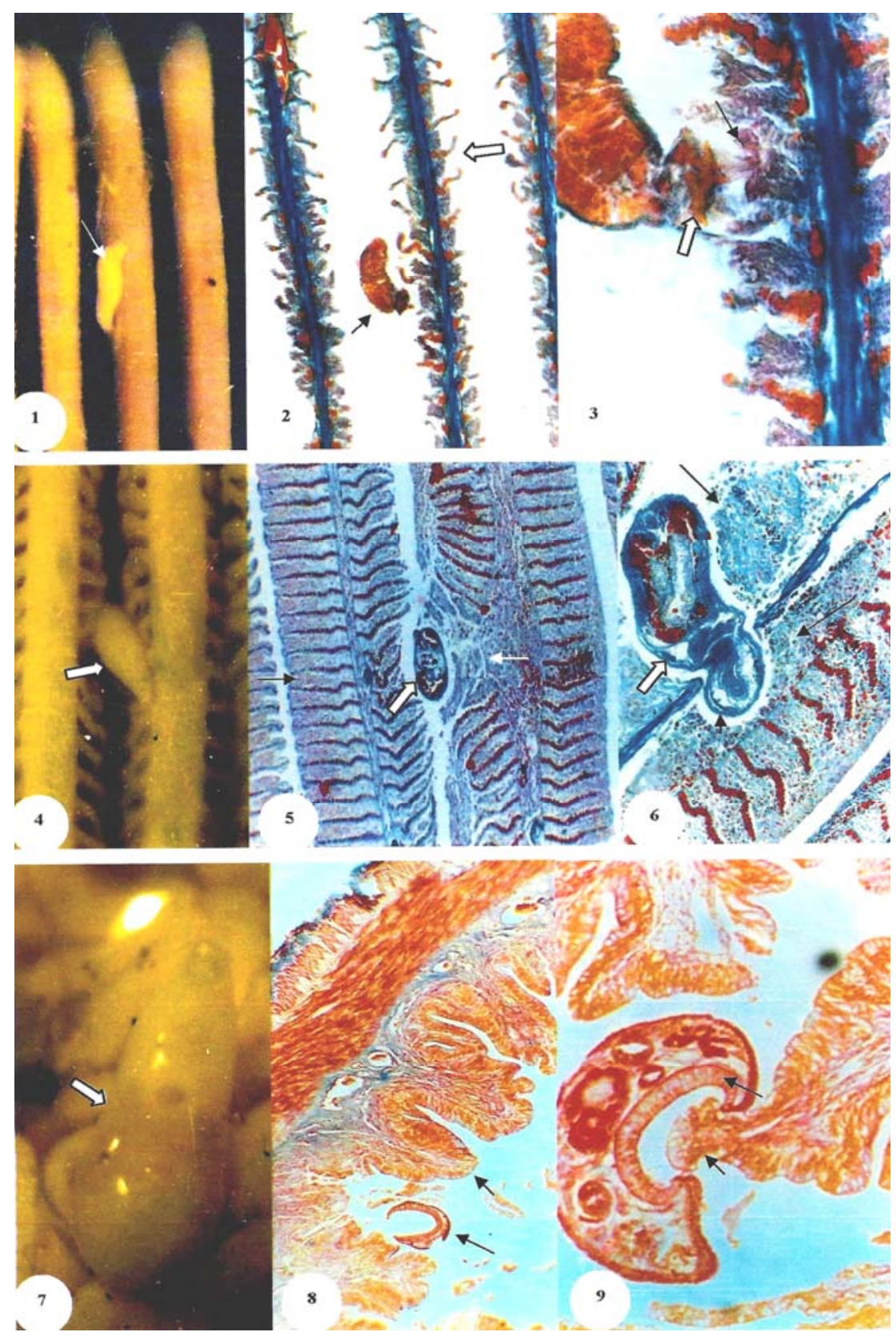

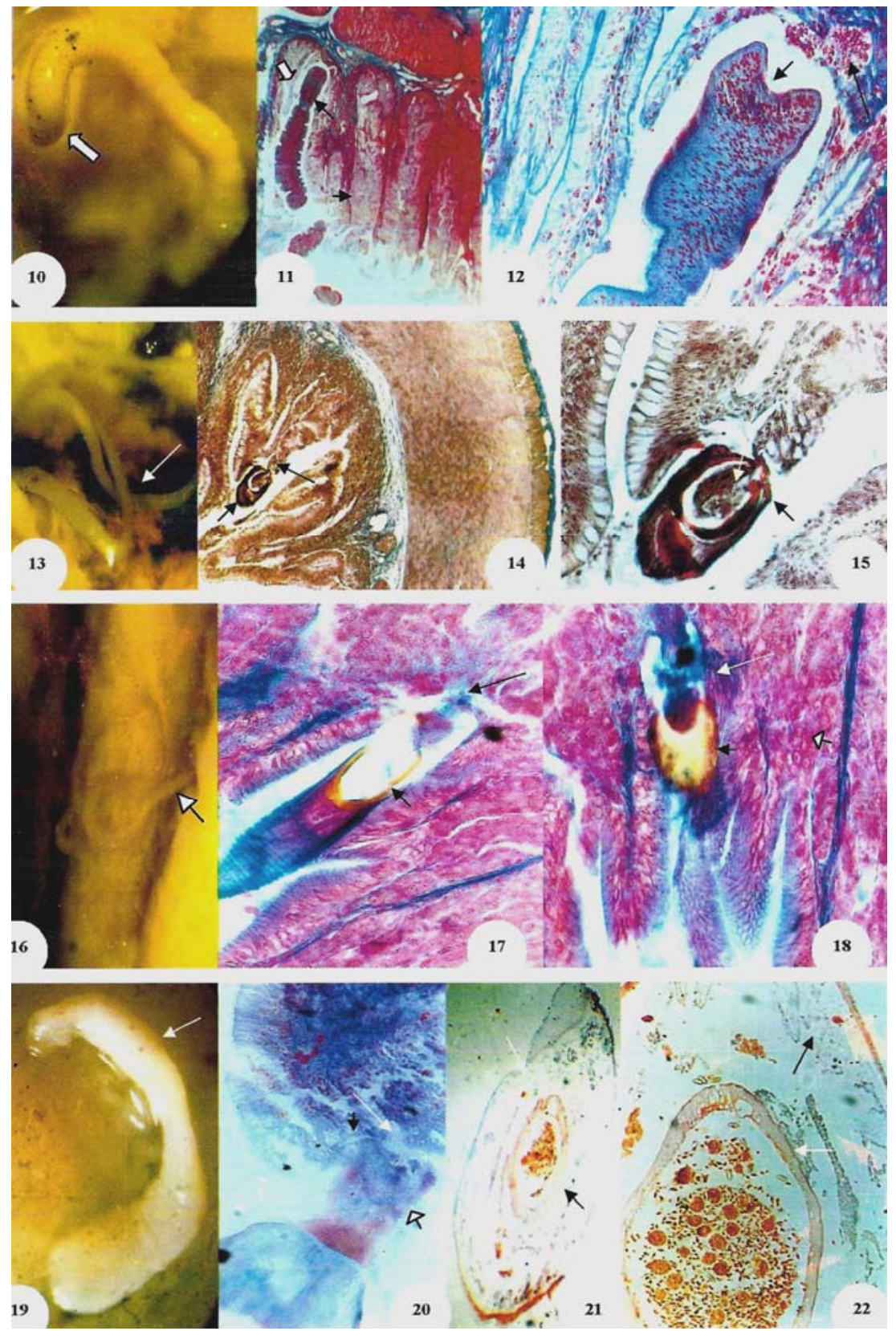